\title{
DA FACULDADE DO JUÍZO COMO FRONTEIRA ENTRE A ESTÉTICA E A POLÍTICA
}

\author{
Luciano da Silva Façanha ${ }^{1}$ \\ Universidade Federal do Maranhão (UFMA) \\ (i) https://orcid.org/0000-0003-1178-4018 \\ Ana Jacira Borges Oliveira ${ }^{2}$ \\ Universidade Federal do Maranhão (UFMA)
}

\section{RESUMO:}

A partir das concepções de Immanuel Kant e Hannah Arendt relativamente à Faculdade do Juízo, esse artigo busca analisar as possíveis conexões entre a nossa capacidade de julgar o belo, e a forma como a Arte Contemporânea articula valores estéticos, morais e cognitivos. Para tanto, apresenta alguns aspectos da apropriação que Arendt faz do juízo estético do gosto que julga o belo, considerando-o como uma categoria política, visando a uma possível associação das manifestações públicas da Arte Contemporânea à ação política de caráter público.

PALAVRAS CHAVE: Arte; Juízo; Política; Kant; Arendt.

\section{THE FACULTY OF JUDGMENT AS THE BORDER BETWEEN AESTHETICS AND POLITICS.}

\begin{abstract}
:
From the ideas of Immanuel Kant and Hannah Arendt regarding Faculty of judgment, this article seeks to analyse the possible connections between our ability to judge the beautiful, and the way in which contemporary art articulate aesthetic values, moral and cognitive. To this end, presents some aspects of appropriation that Arendt makes aesthetic judgment of taste who thinks the beautiful as a political category, aimed at a possible Association of public manifestations of contemporary art to the political action of public character.
\end{abstract}

KEYWORDS: Art; Judgment; Politics; Kant; Arendt.

\footnotetext{
1 Doutor em Filosofia pela Pontifícia Universidade Católica de São Paulo ( PUCSP), São Paulo Brasil. Professor do Departamento de Filosofia, do Programa de Pós-Graduação em Filosofia Mestrado Profissional e do Programa de Pós-Graduação em Cultura e Sociedade da Universidade Federal do Maranhão ( UFMA), Maranhão - Brasil. E-mail: lucianosfacanha@hotmail.com

2 Mestra em Cultura e Sociedade pela Universidade Federal do Maranhão (UFMA), Maranhão Brasil. E-mail: anacrilica@yahoo.com.br
}

FAÇANHA, Luciano da Silva; OLIVEIRA, Ana Jacira Borges. Da faculdade do juízo como fronteira entre a estética e a política. Griot : Revista de Filosofia, Amargosa, Bahia, v.16, n.2, p.221-235, dezembro/2017.

221 


\section{Introdução}

A arte está condicionada à existência humana, pois revela o extraordinário em sua vivência cotidiana. Através dos tempos a arte do homem permanece no mundo e gera sentido, forma, atitude, transformação. Atualmente, as linguagens artísticas aboliram as fronteiras que delimitam técnicas e expressões autônomas, o que torna improvável uma tentativa de definição dos campos de atuação do artista. Por outro lado, as necessidades de consumo e os critérios que definem valor de mercado, ditam muitas vezes a forma do que se poderia chamar de produto artístico. A crise relativa à representação, à noção de arte como obra e à instituição cultural como campo de validação artística, aponta para problemas que evidenciam as mudanças ocorridas no universo das artes visuais a partir dos rompimentos realizados pelas vanguardas no século $\mathrm{XX}$.

Nesse contexto, dentre as expressões artísticas que se destacam na contemporaneidade, temos a arte pública. Cada vez mais, indivíduos e coletivos, se expressam publicamente por linguagens poéticas que misturam performance, instalações, vídeos, murais, dentre outros formatos, e que buscam romper, inclusive, com a noção de validade e qualidade artística, que a arte, enquanto instituição, tem perpetuado. Será que a arte que se apresenta no espaço público pode ser pensada como uma ação pública de caráter político? E ainda, a compressão do Juízo estético kantiano ajuda a pensar a atuação pública da Arte Contemporânea? Assim, a tarefa de pensar a arte como ação pública requer uma investigação das possíveis implicações existentes entre a faculdade humana de julgar o belo conforme estruturado por Kant e a interpretação que Hannah Arendt faz do juízo estético kantiano, observando a noção de juízo "alargado", com vistas a uma consideração sobre o caráter público das artes visuais na contemporaneidade. Nossa hipótese relativa ao caráter público e político da arte, na atualidade, considera que através da interpretação que Hannah Arendt faz do juízo estético kantiano é possível observar a arte como uma forma de expressão política que permite tanto ao sujeito se colocar publicamente quanto às instituições conduzirem suas ideologias aos cidadãos.

Esse processo foi feito a partir de uma observação da analítica do belo que compõe a Crítica da Faculdade do Juízo de Kant, bem como da apropriação que Hannah Arendt faz do juízo estético kantiano, considerando-o como uma categoria política, por uma hermenêutica do contexto vivido pela pensadora, em articulação com o momento das vanguardas modernas $e$ com as artes visuais na contemporaneidade. Assim, o objetivo do presente trabalho é observar as possíveis relações entre a capacidade que a arte tem de sensibilizar o público e as concepções relativas ao juízo reflexivo que, em Kant, está associado ao belo na natureza e na arte e que, em Hannah Arendt, tem relação com a política e com o estar entre homens, que possibilita a existência de um espaço público.

\section{O Juízo estético kantiano}

Em Kant, o objeto é ajuizado como belo pela faculdade da imaginação e não pelo entendimento. Em sua terceira crítica, a representação se refere ao sujeito e a 
seu sentimento de prazer e desprazer. Assim, o sujeito é o fundamento de determinação e o objeto é referência das representações relacionado ao sujeito. Consequentemente, o sentimento de prazer e desprazer funda uma faculdade de distinção e ajuizamento.

No parágrafo três da Crítica da Faculdade do Juízo, Kant define o que está entendendo por complacência, a saber, "sensação de um prazer", ou seja, algo que nos apraz, que nos agrada, e isto pode ser pensado para qualquer faculdade com a mesma propriedade, pois "todas tendem para um objetivo que é para elas um deleite", ou seja, o que está em questão é o "o agrado na sensação de seu estado", que Kant chama também de "efeito sobre o sentimento de prazer" ou complacência. Mais adiante ele diz que não está falando daquela sensação da $1^{a}$ Crítica, isto é, da intuição empírica, não é a percepção de um objeto dos sentidos. Essa sensação ou complacência da qual ele fala, se refere ao sujeito e não ao objeto, como é o caso da que ele apresenta em sua teoria do conhecimento. Assim, a complacência não é um conhecimento ou sensação objetiva, ela é uma sensação subjetiva, pois refere-se ao agrado. A complacência é o efeito sobre o sentimento de prazer, não é a intuição empírica, não é a percepção de um objeto dos sentidos. É uma sensação subjetiva que se refere ao agrado (KANT, 2008, p.50-51).

Na primeira parte da Crítica da Faculdade do Juizo, Kant faz uma análise do belo segundo a qualidade, a quantidade, a relação dos fins e a modalidade da complacência no objeto. Assim, com relação à qualidade, julgamos o objeto como belo representando este objeto pela faculdade da imaginação e não pelo entendimento, pois o juízo de gosto não é um juízo de conhecimento, ele não é lógico e sim estético. Seu fundamento de determinação é subjetivo. A referência da representação é objetiva, porque não designa nada no objeto, "mas no qual o sujeito sente-se a si próprio do modo como ele é afetado pela sensação" (KANT, 2008, p.48). Nessa representação o ânimo torna-se consciente, pois é referido ao sujeito somente.

Se a complacência estiver ligada à representação da existência de um objeto, dizemos que há interesse. Desta forma, esta complacência refere-se à faculdade de desejar e a seu fundamento de determinação. Quando julgamos se algo é belo, não importa a existência do objeto, da coisa, importa o juízo que fazemos na contemplação - intuição ou reflexão. Interessa o que eu faço da representação do objeto em mim. É assim que Kant nos diz que "não se tem que simpatizar minimamente com a existência da coisa, mas ser a esse respeito complacentemente indiferente para em matéria de gosto desempenhar o papel de juiz". (KANT, 2008, p.50).

Parece haver aqui uma oposição entre a complacência pura e desinteressada do juízo de gosto e a complacência ligada a interesse. Rompendo com a tradição platônica que associa o belo à ideia de bem, Kant observa que o agradável, o belo e o bom diferem quanto às representações do sentimento de prazer e desprazer. Assim,

O agradável, o belo, o bom, designam, portanto, três relações diversas das representações ao sentimento de prazer e desprazer, com referência ao qual distinguimos entre si objetos ou modos de representação. Também não são idênticas as expressões que convêm à cada um e com as quais se designa a complacência (Komplazen) nos mesmos. Agradável chama-se para alguém,

FAÇANHA, Luciano da Silva; OLIVEIRA, Ana Jacira Borges. Da faculdade do juízo como fronteira entre a estética e a política. Griot : Revista de Filosofia, Amargosa, Bahia, v.16, n.2, p.221-235, dezembro/2017. 
aquilo que o deleita; belo aquilo que meramente o apraz, bom, aquilo que estimado, aprovado, isto é, onde é posto por ele um valor objetivo (KANT, 2008, p.54).

Para Kant, somente o modo de complacência pelo belo é um modo de complacência desinteressado e livre. A complacência (concordância), no caso do agradável, refere-se à inclinação, no caso do belo, refere-se ao favor e no caso do bom refere-se ao respeito. O favor é a única complacência livre, pois todo interesse pressupõe uma necessidade ou a produz, o que não permite a liberdade do juízo sobre o objeto. Desta forma, relativamente à qualidade, "o gosto é a faculdade de ajuizamento de um objeto ou de um modo de representação mediante uma complacência ou descomplacência independente de todo interesse. $O$ objeto de uma tal complacência chama-se belo". (KANT, 2008, p.55).

O juízo de gosto reivindica a sua validade para qualquer um, sem universalidade fundada sobre objetos e esta é uma reivindicação de universalidade subjetiva. Se uma pessoa toma algo por belo, atribui a outros "a mesma complacência, não julga simplesmente por si, mas por qualquer um e neste caso fala da beleza como se ela fosse uma propriedade das coisas" (KANT, 2008, p.57). Não se pode dizer que cada um possui um gosto particular, pois isso equivaleria dizer que não existe gosto algum. Assim, a qualidade subjetiva do juízo pode ser chamada de validade comum, que designa a validade da referência de uma representação ao sentimento de prazer e desprazer. O juízo sobre o agradável é o gosto dos sentidos e o juízo de gosto sobre o belo é o gosto da reflexão, ambos são juízos estéticos. Assim, com relação à quantidade, "belo é o que apraz universalmente sem conceito" (KANT, 2008, p.63).

O fim que comporta um interesse é aquele que é considerado como fundamento da complacência. Se o fim incide sobre o objeto de prazer, não pode haver fim subjetivo como fundamento do juízo de gosto. O que ocorre é a conformidade a fins subjetivos na representação do objeto, sem qualquer fim. $O$ que ocorre é a simples forma da conformidade a fins. Segundo Imaculada Kangussu, em seu texto Juízos de Kant, é importante ter em mente, quando se fala de conformidade a fins em Kant, o contexto da época da redação da Terceira Crítica, quando a expressão possuía significação diferente daquilo que entendemos hoje como uma finalidade a ser alcançada. Assim,

algo é considerado conforme a fins, quando suas partes estão co-ordenadas, entrelaçadas em uma relação que faz com que o todo não seja um mero ajuntamento de partes avulsas, mas sim uma unidade harmônica. A coordenação interior, relação interna de harmonia entre as partes, que pode por nós ser percebida na forma, independentemente de sabermos a finalidade à qual se destina o objeto, nos causa prazer (KANGUSSU, p.26).

A consciência da conformidade a fins meramente formal no jogo das faculdades de conhecimento do sujeito em uma representação é o prazer. O prazer estético possui a causalidade de manter, sem objetivo ulterior, o estado da própria representação e a ocupação das faculdades de conhecimento. Kant observa que uma 
cor, um som, são considerados belos pela maioria das pessoas, na medida que são puros. Essa determinação concerne à forma e é uma determinação que pode comunicar-se universalmente. A forma constitui o fundamento de toda disposição para o gosto. Nas artes visuais a forma vem a partir do desenho e na música, a partir da composição, e em ambos os casos, constituem o verdadeiro objeto do juízo de gosto puro. Será que a beleza pode ser incorporada ao conceito de perfeição? Segundo Kant,

O juízo de gosto é um juízo estético, isto é, que se baseia sobre fundamentos subjetivos e cujo fundamento de determinação não pode ser nenhum conceito, por conseguinte tampouco o de um fim determinado (KANT, 2008, p. 74).

Portanto, considerando a conformidade a fins, Kant nos diz que "beleza é a forma da conformidade a fins de um objeto, na medida em que ela é percebida nele sem representação de um fim" (KANT, 2008, p.82).

\section{A visão arendtiana}

Para Hannah Arendt, na era moderna, a política passou a ser apenas uma função da sociedade. A sociedade, e não a política, passou a ser vista como o oposto da privacidade moderna. Em nosso mundo atual, cada indivíduo tanto é habitante da Terra quanto de seu país, e Arendt considera que, em meio a esse quadro, os homens modernos foram arremessados para dentro de si mesmos. Em $A$ crise na cultura: sua importância social e política, ${ }^{3}$ Hannah Arendt constata que: "O derradeiro indivíduo que restou na sociedade de massas foi o artista" (ARENDT, 2009 , p.252). Para a autora, o artista é o autêntico produtor dos objetos mais duradouros da cultura, aqueles que a civilização deixa atrás de si como o testemunho duradouro do seu espírito e que, na sociedade de massas é consumido, correndo o risco de ser destruído.

Podemos pensar com Hannah Arendt que no espaço público, o indivíduo se liberta das considerações próprias de sua subjetividade, e adentra o domínio político, o domínio do agir e do falar. O quem "fulano" é se evidencia mais que as qualidades e talentos individuais que ele possua. Assim, o domínio político se opõe ao domínio no qual vivem e fazem seu trabalho o artista e o fabricante. No domínio próprio a

\footnotetext{
${ }^{3}$ Segundo Leonel Ribeiro dos Santos, os principais tópicos que norteiam o texto de Hannah Arendt sobre a crise da cultura são: A política e a arte como fenômenos do espaço público; A cultura e a arte enquanto partilha e gozo da humanidade e como aquilo que dá sentido à política; A ideia de uma comunidade de humanidade fundada não na lógica ou nas prescrições morais, mas no sentido de gosto ou juízo estético; $O$ reconhecimento de que teria sido Kant o primeiro filósofo a ver esses aspectos, na análise que faz do juízo de gosto, ao propor a noção de "modo de pensar alargado" de apreciação e prazer desinteressado, do juízo reflexionante mediante o qual o indivíduo é capaz de colocar-se no lugar do outro e no espaço de comum razão humana para formular e apreciar os seus próprios juízos; Por conseguinte a tese, depois insistentemente repetida, de que é na primeira parte da Crítica do Juízo, e não na Crítica da Razão Prática (nem nas outras obras e escritos onde Kant expressamente expõe a sua filosofia moral e política) que se deve procurar a verdadeira filosofia política de Kant. (SANTOS, 2007).
}

FAÇANHA, Luciano da Silva; OLIVEIRA, Ana Jacira Borges. Da faculdade do juízo como fronteira entre a estética e a política. Griot : Revista de Filosofia, Amargosa, Bahia, v.16, n.2, p.221-235, dezembro/2017. 
esses, o que importa é a qualidade e o talento do fabricante e a qualidade das coisas que ele fabrica. $O$ gosto não julga essa qualidade que está além de discussão e que, assim como a verdade, é coercivamente evidente. Segundo Arendt, a qualidade da obra de arte é auto evidente. $O$ gosto, como atividade da mente culta, aparece quando há uma ampla difusão da consciência-de-qualidade, onde o "verdadeiro belo" é facilmente reconhecível. Ele discrimina e decide entre qualidades e, introduz no âmbito da fabricação e da qualidade, o fator pessoal, humanizando o mundo do belo (ARENDT, 2009, p.279).

A autora considera que os romanos foram um povo intensamente político porque a vida para eles encontrava sentido entre homens. Em seu texto sobre a crise da cultura, ela utiliza o humanismo romano para ilustrar o sentido em que o gosto é a capacidade política que humaniza o belo e cria uma cultura. $O$ vocábulo humanitas foi empregado para traduzir o termo grego filantropia, usado pelos gregos com relação a deuses e governantes. A humanitas romana aplicava-se a homens livres sobre todos os aspectos e a questão da liberdade era fundamental para eles. Destacando Cícero, a autora lembra que o filósofo estoico considerava ser "uma questão de gosto preferir a companhia de Platão e de seus pensamentos, mesmo que isso nos extravie da verdade" (ARENDT, 2009, p.280). Segundo interpretação de Arendt, o humanista não é um especialista, exerce uma faculdade de julgamento e de gosto que está além da coerção das especialidades. Desta forma, Cícero recusa-se a ser coagido, ainda que pela verdade ou pela beleza. O humanismo de Cícero resultado da cultura animi - tem a tarefa de mediar e julgar as atividades políticas e as atividades fabris em suas oposições. "Enquanto humanistas, podemos nos elevar acima desses conflitos entre o político e o artista do mesmo modo como nós podemos elevar em liberdade acima das especialidades que todos aprendemos e exercemos" (ARENDT, 2009, p.280). Assim, podemos estar acima das especialidades se exercitarmos nosso gosto. A autora reforça a importância do pensamento romano que considerava culta a pessoa que soubesse escolher sua companhia entre homens, entre coisas e entre pensamentos, tanto no presente como no passado.

\footnotetext{
Segundo Arendt, o elemento comum à arte e à política é que ambas são fenômenos do mundo público e o que mediatiza o conflito entre o artista e o homem de ação é a cultura animi, ou seja, a posse de um espírito tão formado e tão cultivado que podemos confiar nos que o possuem para vigiarem e cuidarem de um mundo de aparições cujo critério é a beleza. Cícero atribuía essa cultura a uma educação filosófica e os que recebem essa educação estão em condições de abordar as coisas como simples "espectadores", sem desejo de se apropriarem delas para si mesmos (SANTOS, 2007, p.163).
}

Para a autora em questão, o nosso senso de realidade depende da aparência e da existência de um domínio público. Assim, ela lembra que o termo público se refere ao que aparece em público e pode ser visto e ouvido por todos. Constitui a realidade e também o próprio mundo, por ser comum a todos nós. "A importância de ser visto e ouvido por outros provém do fato de que todos veem e ouvem de ângulos diferentes" (ARENDT, 2010, p.70). Pensando a cultura a partir da noção de gosto presente na Crítica da Faculdade do Juízo de Kant, Arendt chama a atenção para a qualidade

FAÇANHA, Luciano da Silva; OLIVEIRA, Ana Jacira Borges. Da faculdade do juízo como fronteira entre a estética e a política. Griot : Revista de Filosofia, Amargosa, Bahia, v.16, n.2, p.221-235, dezembro/2017. 
pública da beleza e observa que o gosto parece decidir como o mundo deve ser visto e ainda, quem pertence a um mesmo grupo ou classe. Assim, "o gosto é a capacidade política que verdadeiramente humaniza o belo e cria uma cultura" (ARENDT, 1992, p.279). Ele é posto, então, como um campo que possibilita o exercício da ação livre e da escolha consciente. A autora lembra que entre os gregos, a palavra gosto era usada para indicar os elementos discriminadores, discernidores e ajuizadores de um amor ativo à beleza - philokalein met euteleias.

A partir desta concepção, Hannah Arendt encontra em Kant, na primeira parte da Crítica do Juízo, uma filosofia política, "a genuína filosofia política kantiana disfarçada sob a análise do juízo estético de beleza" (SANTOS, 2007, p.157). Essa obra contém uma analítica do belo, do ponto de vista do espectador que julga, partindo do fenômeno do gosto em conexão ativa com o que é belo. Na Crítica do Juízo, não basta estar em concórdia com o próprio eu, como no caso das razões teórica e prática. É necessário ser capaz de pensar no lugar dos outros, ter uma mentalidade alargada. Assim, o juízo alude à concórdia potencial com outrem, onde o processo pensante é uma antecipada comunicação com outros, com quem devemos chegar a um acordo. A validade do juízo é obtida deste acordo potencial e os juízos devem se libertar das condições particulares que não são adequadas ao espaço público. Enquanto modo alargado de pensar, o juízo sabe como transcender suas próprias limitações individuais. $\mathrm{O}$ modo alargado de pensar, enquanto juízo, não pode funcionar em estreito isolamento ou solidão e precisa da presença do outro em cujo lugar deve pensar. Desta forma, o juízo, para ser válido, depende da presença de outros. Ele não é universalmente válido e "suas pretensões à validade nunca se podem estender além dos outros em cujo lugar a pessoa que julga colocou-se para suas considerações" (ARENDT, 2009, p.275). Portanto, quem julga é quem pertence ao domínio público e o que ele julga são os objetos do juízo que aparecem no domínio público. Tendo como referência o próprio Kant, Hannah Arendt afirma que o juízo é

\footnotetext{
a misteriosa capacidade do espírito pela qual são reunidos o geral, sempre uma construção espiritual, e o particular, sempre dado à experiência sensível, é uma 'faculdade peculiar' e de modo algum inerente ao intelecto , nem mesmo no caso dos "juízos determinantes" - em que os particulares são subordinados a regras gerais sob a forma de um silogismo -, porque não dispomos de nenhuma regra para as aplicações da regra. Saber como aplicar o geral ao particular é um 'dom natural' suplementar, cuja ausência é 'comumente chamada de estupidez, e para tal falha não há remédio'. A natureza autônoma do juízo é ainda mais óbvia no caso do ‘juízo reflexivo', que não desce do geral para o particular, mas vai 'do particular ... até o universal', quando determina, sem qualquer regra geral, que 'isto é belo', 'isto é feio', 'isto é certo', 'isto é errado'; e, aqui, por um princípio direto, o julgar 'só pode adaptar (se) como uma lei de si mesmo e para si mesmo (ARENDT, 1992, p.55).
}

Segundo Leonel Ribeiro dos Santos, através de suas preocupações que envolvem filosofia e política, Arendt fez uma descoberta pessoal relativa à importância da ação do espírito exercida no julgar e no juízo. Porém não foi buscar essa capacidade no juízo determinante, que tem função lógico-cognoscitiva, mas na faculdade do juízo reflexionante, que tem a função de compreender e dar sentido ou

FAÇANHA, Luciano da Silva; OLIVEIRA, Ana Jacira Borges. Da faculdade do juízo como fronteira entre a estética e a política. Griot : Revista de Filosofia, Amargosa, Bahia, v.16, n.2, p.221-235, dezembro/2017. 
reconhecer a pertinência. Na Crítica do Juízo, Kant apresenta a liberdade como um "predicado" da imaginação e não da vontade. O poder da imaginação é associado ao pensamento político, que é uma forma ampla de pensar, pois nos dá a capacidade de estar no lugar do outro. O autor lembra que, ao afirmar que a atividade política é própria da faculdade de julgar, Hannah Arendt recusa a interpretação que vê como conceito principal da filosofia política de Kant, o imperativo categórico (SANTOS, 2007, p.160). Nesse compartilhar-o-mundo, o julgamento se torna uma atividade importante, talvez a mais importante. Se Kant descobriu este fenômeno do julgamento como um compartilhar com os outros, com todas as implicações políticas que se relacionam ao julgamento, ao examinar o fenômeno do gosto, ele o fez enfrentando o princípio segundo o qual gosto não se discute. Mas ao fazer isso, não subordinou o juízo a regras universais e invocando, ao contrário, uma racionalidade argumentativa "dado que temos a expectativa de que o mesmo prazer que experimentamos pode ser partilhado com outros, então o gosto é um assunto de debate, pois apela ao acordo e consentimento de cada qual" (SANTOS, 2007, p.165).

O gosto se opõe aos "sentimentos íntimos" na medida em que apela ao senso comum. Tanto em juízos estéticos quanto em juízos políticos, tomam-se decisões e as decisões são determinadas por certa subjetividade. Elas decorrem do fato de cada pessoa ocupar um lugar seu, do qual observa e julga o mundo e porque o mundo é um dado objetivo, e comum a todos os seus habitantes. "A atividade do gosto decide como esse mundo, independentemente de sua utilidade e dos interesses vitais que tenhamos nele, deverá parecer e soar, o que os homens verão e ouvirão nele" (ARENDT, 2009, p.276).

O juízo de gosto julga o mundo em sua aparência e temporalidade. Possui um interesse pelo mundo desinteressado, quando pensado pela ótica dos interesses vitais dos indivíduos e pela ótica dos interesses morais do eu. Esses interesses não estão implicados no gosto e são considerados arbitrários. Eles não forçam a um acordo, não são juízos sobre fatos demonstráveis ou verdade racionalmente provada.

Para Hannah Arendt, a cultura e a política se relacionam mutuamente porque não é a racionalidade que está em jogo e sim o juízo e a decisão. Nossa análise baseada no senso comum está intimamente ligada à aparência, mais precisamente à bela aparência, mas também àquilo que aparece pala aparência, e gera valor; provoca juízo de valor.

\footnotetext{
A arte não é política pelo que ela diz, mas por comprometer o espectador a ter que sentir e dizer por conta própria e, assim, assumir-se como corresponsável pela invenção e disseminação de novos sentidos para a arte e para o mundo. $O$ fato deste sentido não estar dado e poder ser de muitas maneiras é o que nos permite ler a autonomia como a garantia de um território experimental (Osório, p. 227).
}

Assim, a faculdade do juízo refere-se a uma capacidade autônoma relativamente ao pensar e ao agir, e com relação ao fazer artístico e à mentalidade alargada, temos que a arte oferece uma ponte entre o pensamento e a ação, pois "é o espectador e não ator que detém a pista para decifrar o sentido dos assuntos humanos" (SANTOS, 2007, p.171).

FAÇANHA, Luciano da Silva; OLIVEIRA, Ana Jacira Borges. Da faculdade do juízo como fronteira entre a estética e a política. Griot : Revista de Filosofia, Amargosa, Bahia, v.16, n.2, p.221-235, dezembro/2017. 
Se a arte passa a ter na modernidade, uma função política, e se a crise na cultura está relacionada ao consumo da obra de arte na sociedade de entretenimento, então a arte passa a exercer na sociedade de consumo papel ideológico, que deve ser apropriado pelo artista como produtor da obra de arte e pelo sujeito em geral, no seu livre exercício do gosto. No texto sobre a crise da cultura, o problema apresentado pela autora com relação à arte na sociedade de massas não é a popularização dos produtos culturais, mas sim a sua destruição, a alteração de sua natureza, ao serem reescritos, condensados ou resumidos a kitsch para o cinema, ameaçando transformar a cultura em mera função para o processo vital da sociedade.

\section{Arte e política}

Dentre as teorias da Arte Moderna que deram origem a expressões artísticas de vanguarda, destacam-se as ideias do artista Marcel Duchamp que, com seus readymades, questionou a noção de preciosidade do objeto artístico. $\mathrm{O}$ ready made transfere o valor de obra de arte para um objeto comum, "retirando-o de um contexto em que, por serem todas as coisas utilitárias, nada pode ser estético, situando-o numa dimensão na qual, nada sendo utilitário, tudo pode ser estético" (ARGAN, 1992, p. 358). Ao nomear um aparelho sanitário com o título de fonte e apresentá-lo como obra em um salão, Duchamp demonstrou que o valor artístico daquele objeto estava no juízo que um sujeito fazia dele ${ }^{4}$, e que o que determina o valor estético é uma atitude diferente, um ato mental, e não a maestria técnica. Ele foi um pintor de ideias e chamava a pintura de olfativa, pelo cheiro da terebintina, e retiniana, por ser puramente visual. Considerava a metaironia como uma lei das artes por ser inerente ao próprio espírito, sendo que essa ironia se torna afirmativa ao negar sua própria negação (PAZ, 2012, p.10). Assim, abandonou a pintura tradicional abraçando o movimento dadaísta. Duchamp torna-se então, um dos principais representantes do movimento que pregava a substituição da obra de arte pelo ato estético. Para Giulio Argan, o Dadaísmo surge como uma contestação de todos os valores, aos quais incluíram a arte. Esse movimento ocorreu simultaneamente na Europa e nos Estados Unidos, em um momento em que a crise na cultura promovida pela Primeira Guerra Mundial torna-se a crise dos valores que sustentam a noção de arte. Dessa forma, a preocupação da arte dissocia-se de valores culturais que remetem ao status da burguesia e ao filisteísmo, evidenciando o acaso nonsense, e a arte se transforma, então, em existência.

Após a Segunda Guerra Mundial, o centro da cultura artística moderna passa a ser Nova York. Os americanos se apropriam, então, da arte europeia. A action painting $^{5}$ e a arte pop são resultados de uma maneira diferente de fazer arte no novo

\footnotetext{
${ }^{4}$ Não podemos deixar de observar aqui a relação com as concepções arendtianas no que concerne ao juízo estético kantiano e que serão colocadas no terceiro capítulo.

${ }_{5}^{5}$ Jackson Pollock por exemplo, assim se referia a sua produção artística: Quando estou no meu quadro não tenho consciência do que estou fazendo. Só depois de uma espécie de período de "conhecimento" é que vejo o que estive fazendo. Não tenho medo de fazer modificações, de destruir a imagem, etc, porque o quadro tem uma vida própria. Procuro deixar que esse mistério se revele (CHIPP, 1999, 556).
}

FAÇANHA, Luciano da Silva; OLIVEIRA, Ana Jacira Borges. Da faculdade do juízo como fronteira entre a estética e a política. Griot : Revista de Filosofia, Amargosa, Bahia, v.16, n.2, p.221-235, dezembro/2017. 
mundo: a criação imediata de "fatos estéticos" (ARGAN, 1992, p.507). Os exilados que chegam aos Estados Unidos também fazem experiências com a performance. Membros da Bauhaus, dentre outros, criam o Black Mountain College, que adquire fama como instituição experimental. Ao mesmo tempo, John Cage e Merce Cunningham desenvolvem propostas com o som e o ruído e passam a realizar apresentações que buscam lidar com a "totalidade do campo sonoro", cuja inspiração remete ao zen-budismo. Em 1952, Cage chegou à Obra silenciosa, experiência radical onde nenhum som era produzido intencionalmente, evidenciando que, como tudo na vida, a arte não é nem boa nem má (GOLDBERG, 2006, p. 113). Na década de 60, estrangeiros e americanos que haviam participado do curso de Cage, criaram o movimento Fluxus, que não se caracterizava como escola ou grupo de artistas e sim como "um modo de viver". O Fluxus foi comparável ao Dadaísmo e militou intensamente em todos os setores da criação artística, influenciando de diversas maneiras a Arte Contemporânea (GLUSBERG, 2005, p.133-136).

Nos anos 60 e 70, período de grande produção de Hannah Arendt, a arte reflete a negação à narrativa, ao Academicismo, ao drama e ao Expressionismo. Nesse período, a produção artística preocupa-se com a abstração. Em 1965, a coreógrafa Yvone Rainer escreve o Manifesto da Renúncia, no qual nega os vários elementos que compõem a narrativa, tais como transcendência da imagem, heroísmo, estilo e outros. Kátia Canton observa que a estratégia utilizada era a adoção de métodos anti-ilusionistas ou antinarrativos, pois o ilusionismo na arte gera identificação entre espectador e obra, revelando significados. Em contrapartida Canton afirma que

\footnotetext{
O uso consistente da narrativa tornou-se progressivamente uma âncora para a representação contemporânea. A década de 80 , chamada nos Estados Unidos de a era dos yuppies-dos jovens urbanos que enriqueceram com o mercado financeiro - substituiu as experiências da vanguarda e o senso de comunidade artística por um recrudescimento do consumismo e um fascínio pela opulência (CANTON, 2001, p.19).
}

No decorrer do século XX e através das experiências mais variadas e radicais, o objeto artístico foi sendo questionado, apropriado e desmaterializado. Dele se diz que é feito para a contemplação e que possui autonomia, com presença e entidade material bem definida. Pode assim ser vendido ou transportado e é feito para o olhar do espectador, cujas relações formais possuem objetividade. Muitas vezes são criados com intenções mágicas, religiosas ou políticas, mas, geralmente, correspondem ao interesse do mercado e ao espaço destinado a eles em instituições culturais (ROCHA, 2002 , p.77). Nesse contexto, a relação entre os produtos das vanguardas e o conceito de obra de arte se torna problemática. Mas, será que o conceito de obra entrou em crise ou, por outro lado, foi uma determinada noção de obra que se tornou problemática?

Para Peter Bürger, em sentido amplo, a obra de arte é definida como a unidade do geral e do particular. Este autor diferencia obra orgânica - simbólica - de obra não-orgânica - alegórica. No caso da obra orgânica, ele considera que não há mediação na sua relação com o geral e na não-orgânica, que há mediação entre o particular e o geral. As obras não-orgânicas são as de vanguarda que, mesmo nas

FAÇANHA, Luciano da Silva; OLIVEIRA, Ana Jacira Borges. Da faculdade do juízo como fronteira entre a estética e a política. Griot : Revista de Filosofia, Amargosa, Bahia, v.16, n.2, p.221-235, dezembro/2017. 
versões mais radicais, relacionam-se com a categoria de obra, embora de forma negativa, onde o próprio ato de provocação assume o lugar da obra. "É fato histórico, entretanto, que também depois dos movimentos de vanguarda obras de arte continuaram a ser produzidas, e que a instituição arte acabou por se mostrar resistente ao ataque vanguardista (BÜRGER, 2008, p. 120).

Vivemos hoje uma fase pós-vanguardista, onde podemos observar que a categoria de obra de arte foi restaurada e ampliada - os ready mades e objet trouvé, por exemplo, são ressignificações de objetos retirados casualmente de contexto nãoartístico -, passando a conviver com os procedimentos inventados pelas vanguardas. Além disso, a instituição arte continua a existir e não foi integrada à práxis vital. Para Peter Bürger, toda produção artística da atualidade deve considerá-la e não pode negar sua verdade. Isso ocorre porque as vanguardas se tornaram fato histórico e seus procedimentos reativos se tornaram produtos da instituição arte, que não perdeu sua autonomia e não se tornou parte da vida cotidiana. Porém, isso não significa dizer que as vanguardas tenham sido invalidadas, pelo contrário, elas destruíram o conceito de obra orgânica e colocaram em seu lugar a obra nãoorgânica. (BÜRGER, 2008, p. 118).

A superação das vanguardas remete à Pós-modernidade. Eleanor Heartney pontua o surgimento do estilo pós-moderno por volta dos anos 80 , resultado da junção do pós-modernismo e pós-estruturalismo. Novos princípios passaram a reger a atividade artística, ocorrendo uma revolução contra a fé modernista relativa à universalidade da arte, progresso artístico e qualidade intrínseca da obra, dentre outras convicções modernas. A definição daquilo que, na contemporaneidade, se afirmou como Pós-moderno, se dá de forma reativa, pela negação da Modernidade. Assim, o Pós-modernismo pode ser uma reação ao modernismo, um retorno ao que antecede o modernismo ou continuação de tendências iniciadas no modernismo. Enfim, definir pós-modernismo só é possível em presença do moderno (cf. HEARTNEY, 2002: 6). Porém, podemos dizer que o que caracteriza a pósmodernidade é a remoção da realidade, sem que tal remoção seja sentida pelo público. Eleanor Heartney exemplifica essa proposição citando a guerra do Golfo, que trouxe ao público televisivo imagens semelhantes a jogos de videogame, o que resultou em uma noção abstrata de guerra. A autora diz que, tais situações, sustentam o dogma pós-moderno no qual nossa compreensão de mundo é baseada em imagens mediadas onde cada uma "afirma uma noção de que vivemos dentro da esfera de influência de uma mitologia invocada para nós pela mídia, pelo cinema e pela publicidade" (HEARTNEY, 2002, p.7).

Ao final da década de 80 ocorre na arte um retorno ao objeto, mas não um objeto de arte estetizado. Ele veio acompanhado de termos como "simulacro", "hiper-realidade", "cumplicidade crítica" e "críticos do mercado". Nos anos 90, a definição de arte passou a apresentar o reflexo de um percurso de experimentações das vanguardas desenvolvidas ao longo de século 20. De Marcel Duchanp, que trouxe para o mundo da arte os readymades, passando pela arte conceitual nas décadas de 60 e 70, que priorizou o processo, das propostas artísticas que substituíram o valor do produto enquanto artesania, até à utilização pelos artistas de meios tecnológicos, os limites do universo artístico se desmancharam. Nesse

FAÇANHA, Luciano da Silva; OLIVEIRA, Ana Jacira Borges. Da faculdade do juízo como fronteira entre a estética e a política. Griot : Revista de Filosofia, Amargosa, Bahia, v.16, n.2, p.221-235, dezembro/2017. 
momento, questões como a "morte da pintura" perderam o sentido, não cabendo mais discussões acerca dos suportes. Pintura, escultura, instalações, objetos, textos e internet misturam-se e a preocupação com o sentido substitui aquela ligada ao meio. Essa busca de sentido que, por um lado, está voltada para as questões formais próprias da arte, por outro lado, persegue a compreensão da realidade, explorando universos variados, tais como a política, a economia, a educação e a cultura.

\begin{abstract}
A produção contemporânea não é uma produção de negação, como foi a produção moderna de vanguarda. As experimentações realizadas no percurso do século 20 foram apreendidas e incorporadas, injetadas, no entanto, dessa busca de sentido que se liga às especificidades de um novo contexto sócio histórico. (CANTON, 2001, p.30).
\end{abstract}

Assim, as pesquisas desenvolvidas pelas vanguardas foram apropriadas pelas novas gerações, que somaram a elas uma busca de sentidos e criando narrativas fragmentadas. Kátia Canton, baseada em pesquisa realizada através de questionário junto a artistas, diz que a maioria dos entrevistados definiu sua arte não por aspectos estruturais, e sim pela capacidade de se posicionar diante do mundo. A curadora afirma que a ação artística contemporânea é prioritariamente individual, pois não parte de um projeto sócio-político específico e não está ligada a movimentos ou manifestos. Baseada em formas de expressão íntima e pessoal para estabelecer sentidos, essa arte busca conexão com o observador, pretendendo incomodar e levar a posturas diante do mundo e da vida. Para Kátia Canton

\footnotetext{
Arte é texto. É comentário sobre o tempo e a vida, que toma o corpo de uma escritura, tão subjetiva como o próprio alfabeto. Arte é hieróglifo, forma que clama sentido e sensibilidade. É conhecimento, flexível, porém imprescindível - um conhecimento que se abre ao observador como um estranho livro em que a narrativa contida se assume de acordo com seu próprio olhar (CANTON, 2001, p.37).
}

\title{
Considerações finais
}

O poético se distingue do discurso por sua ambiguidade, onde não há uma construção lógica da mensagem e a relação entre signo e mensagem é modificada. A ação poética contraria o encadeamento próprio à categoria de meios e fim, ressaltando a maneira de agir e convertendo a escolha do procedimento em objetivo (ROCHA, 2009, p.65). A intenção artística, nesse caso, gera um amplo espaço de reflexão que alarga nossa percepção, provoca reações variadas e, podemos dizer, "imprevisíveis". A ação poética compartilha também da perecibilidade da ação. Ela se completa retrospectivamente na medida em que vai se constituindo no processo entre homens e por intermédio de suas significações de vida.

Porém, se a arte pressupõe o fazer do artista e o produto desse fazer, parece que o termo ação poética, em última instância, remete a uma fabricação da ação. $O$ estudo da obra de arte em processo refere-se à Poiética - poïétique -, termo cunhado por Paul Valéry para estudar a gênese de um poema e ampliado por René Passeron para o conjunto de estudos que tratam da criação na instauração da obra de arte, gerando a pesquisa em poéticas visuais sobre o modo de existência da obra se fazendo

FAÇANHA, Luciano da Silva; OLIVEIRA, Ana Jacira Borges. Da faculdade do juízo como fronteira entre a estética e a política. Griot : Revista de Filosofia, Amargosa, Bahia, v.16, n.2, p.221-235, dezembro/2017. 
(REY, 2002, p.134). Porém, essa criação que a obra de arte na contemporaneidade instaura, se traduz em processo que se faz entre homens, sendo constituída no ato mesmo do fazer. Essa diferença entre uma artesania que transmuta forças elementares para a permanência do artifício humano, e um fazer-se que instaura processos entre artista e espectadores, remete à produção de sentido e à ideia de Hannah Arendt de arte como produto do pensamento. Ao mesmo tempo, confere à arte elementos daquilo que, em Kant, inverte a ordem da causalidade, ea representação do efeito passa a preceder a causa (LACOSTE, 1986, p.29).

Na Arte Contemporânea, e mais precisamente na arte pública, a obra não é estimada como valor para o mercado de trocas. O espaço no qual ela articula sentidos é o espaço das relações humanas em que os indivíduos se encontram entre pares por sua capacidade de pensar, refletir sobre questões comuns e exercer sua autonomia ao lidar com situações que levem à possibilidade de escolhas e consequente mudanças. As manifestações da Arte Contemporânea articulam significados de indivíduos através de uma mitologia urbana e instauram um espaço comum que possibilita a ação política a cada sujeito que entre em contato com esse espaço, uma vez que esta ação ocorre entre homens e em contextos reflexivos que possuem um espaço público comum.

Será que a arte promove uma abertura pública? Ao apreendermos determinado conteúdo, conseguimos obter um dado conhecimento, e isso se dá pela forma. $\mathrm{O}$ aparecer da arte como produto do pensamento pode apontar para uma comunicação pela mentalidade alargada que o juízo estético tende a promover. A descoberta da noção de informe leva a pensar sobre a transgressão de contextos instituídos, levando a outras possibilidades formais. Essa abertura da obra oferece contexto propício para pensarmos a arte como ação pública. Pela ação presencial da performance, por exemplo, temos as configurações do tempo na poética contemporânea. Nesse sentido, a Arte Contemporânea evidencia a condição de pluralidade do homem no mundo.

As manifestações da Arte Contemporânea refletem a coletividade na construção da obra de arte, considerando o fazer que se constitui no próprio processo. Essa poética relaciona artista e espectador de forma imbrincada, articulando sentidos entre indivíduos e desencadeando processos imprevisíveis a partir de propostas pensadas com embasamento e pesquisa. As fronteiras que foram desmanchadas com relação às linguagens não comportam também as determinações existenciais dos condicionamentos humanos. Arte é obra, ação e trabalho, mas é principalmente, segundo Hannah Arendt, produto de um pensamento que, ao se alargar pela poética, produz reflexão e autonomia. Nesse contexto, cada indivíduo que nasce é provocado a pensar, opinar e criar, agindo e provocando novas reações imprevisíveis.

FAÇANHA, Luciano da Silva; OLIVEIRA, Ana Jacira Borges. Da faculdade do juízo como fronteira entre a estética e a política. Griot : Revista de Filosofia, Amargosa, Bahia, v.16, n.2, p.221-235, dezembro/2017. 


\section{Referências bibliográficas}

ARCHER, Michael. Arte contemporânea. Uma história concisa. Tradução de Alexandre Krug e Valter Siqueira. São Paulo: Martins Fontes, 2001. Coleção a.

ARENDT, Hannah. A vida do espírito: o pensar/ o querer/ o julgar. Rio de Janeiro: Relume-Dumará - Ed. UFRJ, 1992.

- A condição humana. Rio de janeiro: Forense Universitária, 2010.

. The human condition. Chicago: University of Chicago Press, 1998.

Entre o passado e o futuro. São Paulo: Perspectiva, 2009.

Origens do totalitarismo: anti-semitismo / imperialismo / totalitarismo. São

Paulo: Companhia das Letras, 2009.

Homens em tempos sombrios. São Paulo: Companhia das Letras, 2008.

Companhia de Bolso.

Lições sobre a filosofia política de Kant. Org. Ronald Beiner. Tradução de André Duarte. Rio de janeiro: Relume-Dumará, 1994.

ARGAN, Giulio Carlo. Arte moderna. Do Iluminismo aos movimentos contemporâneos. Tradução: Denise Bottmann e Federico Carotti. São Paulo: Companhia das Letras, 1992.

ARISTÓTELES. Arte retórica e arte poética. Rio de janeiro: edições de Ouro, s/d. Coleção Universidade.

. Ética a Nicômaco. Ética a Nicômaco. Edição bilíngue e tradução de Maria Araújo e Julián Marías. Madri: Centro de Estudios Políticos y Constitucionales, 2002 .

1998. A política. Tradução de Roberto Leal Ferreira. São Paulo: Martins fontes,

BARTHES, Roland. O óbvio e o obtuso. Rio de Janeiro: Nova Fronteira, 1990. - A aventura semiológica. São Paulo: Martins Fontes, 2001.

BÜRGER, Peter. Teoria da vanguarda. Tradução de José Antonio. São Paulo: Cosac Naify, 2008.

CANTON, Kátia. Novíssima arte brasileira: um guia de tendências. São Paulo: Iluminuras, 2001.

GARVALHO, Castelar de. Para compreender Saussure. Petrópolis: Vozes, 1997.

CHIPP, Herschel Browning. Teorias da arte moderna. São Paulo: Martins Fontes, 1996.

COSTA, Luís Inácio Oliveira. Ação e narração em Hannah Arendt. Olhar, São Carlos, SP, ano 5, n.9, p. 54-62, dez., 2003.

GLUSBERG, Jorge. $A$ arte da performance. Tradução de Renato Cohen. São Paulo: Perspectiva, 1987.

GOLDBERG, Roselee. A arte da performance. Do Futurismo ao presente. Tradução de Jefferson Luiz Camargo. Revisão técnica de Kátia Canton. São Paulo: Martins fontes, 2006. Coleção a.

HEARTNEY, Eleanor. Pós-modernismo. São Paulo: Cosac e Naify, 2002.

JARDIM, Eduardo. Hannah Arendt: pensadora da crise e de um novo início. Rio de Janeiro: Civilização Brasileira, 2011.

FAÇANHA, Luciano da Silva; OLIVEIRA, Ana Jacira Borges. Da faculdade do juízo como fronteira entre a estética e a política. Griot : Revista de Filosofia, Amargosa, Bahia, v.16, n.2, p.221-235, dezembro/2017. 
KANGUSSU, Imaculada Maria Guimarães. Juízos determinantes e juízos reflexivos. Disponível em: http://www.academia.edu/1079286/Ju\%C3\%ADzos_de_Kant. Acesso em 23 de Abril de 2015.

KANT, Imanuel. Crítica da faculdade do juízo. Rio de Janeiro: Forense Universitária, 2008.

LACOSTE, Jean. A filosofia da arte. Rio de Janeiro: Jorge Zahar,1986.

LYOTARD, Jean-François. A condição pós-moderna. Rio de janeiro: José Olympio, 1979.

MICHELI, Mário de. As vanguardas artísticas. Tradução de Pier Luigi Cabra. São Paulo: Martins Fontes, 2004.

NUNES, Benedito. Introdução à filosofia da arte. São Paulo: Ática, 1991.

OSÓRIO, Luiz Camillo. Da arte e do espectador contemporâneos: Contribuições a partir de Hannah Arendt e da Crítica do Juízo. Disponível em: www.oquenosfazpensar.com/adm/uploads/artigo/da_aete_e_do_espectador_contemp oraneos:_contribuicoes_a_partir_de_hannah_arendt_e_da_critica_do

juizo/luiz c osorio 219-234.pdf. Acesso em 15 de julho de 2014.

PAZ, Octavio. Marcel Duchamp ou o castelo da pureza. Tradução de Sebastião Uchoa Leite. São Pulo: Perspectiva, 2012.

REY, Sandra. Por uma abordagem metodológica da pesquisa em artes visuais. In: O meio como ponto zero: metodologia da pesquisa em artes plásticas. Porto Alegre: Ed. Universidade/UFRGS, 2002.

ROCHA, Viviane Moura da. A rosa cintilante: sobre a experiência estética sublime na poética de Artur Barrio. Dissertação de Mestrado. Universidade Federal do rio Grande do Sul. Instituto de Artes. Programa de Pós-Graduação em Artes Visuais. Porto Alegre, 2002.

Ações poéticas. A Performance como ruptura de limites e plasticidade do tempo. Tese de doutorado. Universidade Federal do Rio Grande do Sul. Institutos de Arte. Programa de Pós-Graduação em Artes Visuais. Porto Alegre, 2009.

SANTOS, Leonel Ribeiro. Da estética como filosofia política: Hannah Arendt e a interpretação da Crítica do Juízo de Kant. In: Hannah Arendt: luz e sombra. Lisboa: Centro de Filosofia da Universidade de Lisboa, 2007.

VERNANT, Jean-Pierre. Mito e pensamento entre os gregos. Estudos de psicologia histórica. Rio de Janeiro: Paz e Terra, 1990.

YOUNG-BRUEHL, Elizabeth. Por amor ao mundo: A vida e a Obra de Hannah Arendt. Tradução de Antônio Trãnsito. Rio de Janeiro: Relume-Dumará, 1997.

Contribuição dos autores:

Luciano da Silva Façanha contribuiu com as pesquisas em torno da Faculdade do Juízo em Kant e os possíveis diálogos com outros autores. Ana Jacira Borges contribuiu com as pesquisas sobre Hannah Arendt, principalmente, a forma como a autora se apropria da questão do Juízo estético em Kant e as formas como a Arte contemporânea realiza essas conexões.

Autor(a) para correspondência: Luciano da Silva Façanha, Universidade Federal do Maranhão, Av. dos Portugueses, 1966, Vila Bacanga, CEP 65080-805, São Luís - MA, Brasil. lucianosfacanha@hotmail.com

FAÇANHA, Luciano da Silva; OLIVEIRA, Ana Jacira Borges. Da faculdade do juízo como fronteira entre a estética e a política. Griot : Revista de Filosofia, Amargosa, Bahia, v.16, n.2, p.221-235, dezembro/2017. 